\title{
Work and Health: A Challenge to Health Care ${ }^{1}$
}

\author{
Ronald JB* \\ Department of Organizational Studies, York University, Canada
}

Submission: May 11, 2017; Published: May 25, 2017

*Corresponding author: Ronald JB, Department of organizational Behaviour \& Industrial Relation, York University, Canada, Email: rburke@schulich.yorku.ca

\section{Opinion}

Sigmund Freud wrote that two areas contributed to human happiness, fulfilment and health - love and work, "leiben und arbeiten". Freud also thought that most people did not find work satisfying; they worked because they had to. Freud may have been wrong in some of his other writing, but sadly he was right here.

Adults will spend about one third of their waking hours at work, the average person spending about 70,000 hours working and some people spending over 120,000 hours working. Some people enjoy their work continue to work beyond normal retirement age. Work can give pleasure and pain.

There is considerable evidence on the pain side of work workplace stress has been identified as leading causes of health problems at work. Goh [1] examined the combined effects of workplace stress on health in terms of individual mortality rates and health costs. They used meta-analysis to study excess mortality and increasing health costs associated with ten stressors These stressors were unemployment, exposure to shift work long work hours, job security, work-family conflict, low job control, high job demands, low social support at work, low organizational justice, and lack of health insurance. Outcome variables were mortality rates and health care spending.. They found that about 1,20,000 deaths and 5\% to $8 \%$ of annual health care costs were directly associated with these stressors and indirectly to the ay employees were managed in US organizations.

Quick \& Cooper [2] write that workplace stress has been shown to be directly or indirectly related to seven of the ten leading causes of death in developed nations. These seven, in order, are heart disease; cancer; stroke; injuries; suicide/homicide; chronic liver disease; and emphysema, chronic bronchitis.

Increasing research attention as well as country legislation has now focused on work and well-being [3]
This has produced research and writing on the importance of creating psychologically healthy workplaces as a way of reducing employee health problems and health costa as well as increasing organizational performance and success [4-6]. Unfortunately psychologically unhealthy workplaces are much more common today than are psychologically healthy workplaces.

Psychologically unhealthy workplaces are characterized by some of the following: toxic leadership, bullying workplace incivility, sexual harassment, racial and gender discrimination, high levels of organizational politics, and unsafe working conditions. Employees in these workplaces are under high levels of stress, exhibit low levels of work engagement, high job dissatisfaction, low performance and high levels of distress associated with reduced levels of emotional and physical well-being. Empluees here are the "walking wounded".

Day \& Randell [7] define psychologically healthy workplaces as "workplaces that aim to reduce negative demands and stressors but also promote organizational resources to improve wellbeing". Wellbeing is an umbrella term that includes outcomes such as satisfaction, engagement, flow, flourishing, thriving, commitment, helpfulness, compassion, and high levels of emotion, physical and physiological health.

Kelloway \& Day [6] propose six antecedents of healthy workplaces: a safe work environment; presence of worklife balance; a culture of organizational support, respect and fairness; employee involvement and development; positive task content and characteristics, and interpersonal relationships at work.

Interest in creating psychologically healthy workplaces has also been influence by earlier writing on positive psychology and positive organizational scholarship. Psychologists noted that much of the early work in psychology focused on illness and pathology instead of growth and joy. Positive psychology focused a 
lens on positive emotions such as compassion, gratitude, virtuousness and thriving. Positive organizational scholarship introduced positive processes, strategies and outcomes into organizational life [8]. This work has led to a number of evaluations of the benefits of positive practices in organizations on both individual and organizational health [9]. Corporate wellness programs are also proving to be helpful in improving employ, but these efforts do not bring about major cultural changes in the application of positive processes in most instances.

This short note calls for a stronger working relationship between the providers of health care, in both promoting high levels of well-being as well as dealing with casualties, with corporate leaders. As more organizations work to become more psychologically healthy workplaces through the application of positive organizational practices, reductions in those needing health care assistance will be realized. This will still be a major challenge as changing organizational cultures requires resources, commitment and time.

${ }^{1}$ Preparation of this manuscript was supported in part by York University.

\section{References}

1. Goh J, Pfeffer J, Zenios SA (2015) The relationship between workplace stressors and mortality and health costs in the United States. Management Science 62(2): 608-628.

2. Quick JC, Cooper CL (2003) Stress and strain, Oxford: Health Press, USA.

3. Burke RJ, Page K (2017) Research handbook on work and well-being. Cheltenham: Edward Elgar, England.

4. Grawitch MJ, Ballard DW (2016) The psychologically healthy workplace: Building a win-win environment for organizations and employees, American Psychological Association, Washington DC, USA.

5. Day A, Kelloway EK, Hurrell JJ (2014) Workplace wellbeng: How to build psychologically healthy workplaces, USA.

6. Kelloway EK, Day A (2005) Building psychologically healthy workplaces: What we know so far. Canadian Journal of Behavioral Science 37(4): 223-235.

7. Day A, Randell KD (2014) Building a foundation for psychologically healthy workplaces and well-being. In: Day A, Kelloway EK, Hurrell IJ (Eds.), Workplace well-being: How to build psychologically healthy workplaces,USA, pp. 3-26

8. Cameron KS, Dutton JE, Quinn RE (2003) Positive organizational scholarship. San Francisco: Berrett-Koehler, USA.

9. Cameron KS, Mora C, Leutscher T, Calarco M (2011) Effects of positive practices on organizational effectiveness. Journal of Applied Behavioral Sciences 47: 266-308.

Your next submission with Juniper Publishers will reach you the below assets

Commons Attribution 4.0 License
- Quality Editorial service

- Swift Peer Review

- Reprints availability

- E-prints Service

- Manuscript Podcast for convenient understanding

- Global attainment for your research

- Manuscript accessibility in different formats (Pdf, E-pub, Full Text, Audio)

- Unceasing customer service

Track the below URL for one-step submission https://juniperpublishers.com/online-submission.php 